\title{
Person of the Issue: William James (1842-1910)
}

\section{Ankit Patel $_{1}$}
Born
January 11, 1842
New York City, New York
Died
August 26, 1910 (aged 68)
Tamworth, New Hampshire
$\begin{array}{ll}\text { Alma mater } & \text { Harvard University } \\ \text { Religion } & \text { Western Philosophy }\end{array}$
Religion Western Philosophy
Era 19th/20th century philosophy

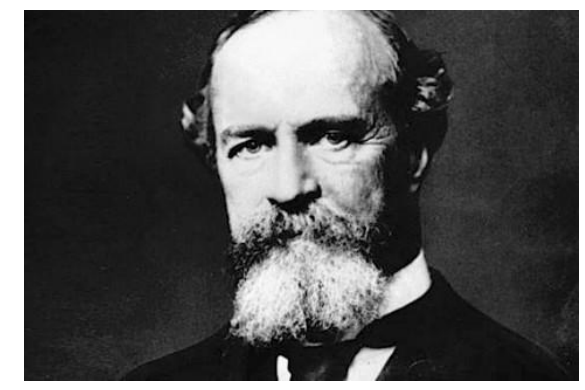
School Functional psychology
Radical empiricism
Main interests Pragmatism, psychology, philosophy
of religion, epistemology, meaning

William James was an original thinker in and between the disciplines of physiology, psychology and philosophy. His twelve-hundred page masterwork, The Principles of Psychology (1890), is a rich blend of physiology, psychology, philosophy, and personal reflection that has given us such ideas as "the stream of thought" and the baby's impression of the world "as one great blooming, buzzing confusion" (PP 462). It contains seeds of pragmatism and phenomenology, and influenced generations of thinkers in Europe and America, including Edmund Husserl, Bertrand Russell, John Dewey, and Ludwig Wittgenstein. James studied at Harvard's Lawrence Scientific School and the School of Medicine, but his writings were from the outset as much philosophical as scientific. "Some Remarks on Spencer's Notion of Mind as Correspondence" (1878) and "The Sentiment of Rationality" $(1879,1882)$ presage his future pragmatism and pluralism, and contain the first statements of his view that philosophical theories are reflections of a philosopher's temperament.

William James was born in New York City on January 11, 1842, into an intellectual household; his father was a philosopher and his brother, Henry James, grew up to become a renowed novelist. After medical school, James focused on the human psyche, writing a masterwork on the subject, entitled The Principles of Psychology. He later became known for the literary piece The Will to Believe and Other Essays in Popular Philosophy, which was published in 1897. James died on August 26, 1910, in Chocorua, New Hampshire.

\footnotetext{
${ }^{1}$ MA, Clinical Psychology, Dept. of Psychology, Sardar Patel University, Vidhyanagar, Gujrat
} 
James hints at his religious concerns in his earliest essays and in The Principles, but they become more explicit in The Will to Believe and Other Essays in Popular Philosophy (1897), Human Immortality: Two Supposed Objections to the Doctrine (1898), The Varieties of Religious Experience (1902) and A Pluralistic Universe (1909). James oscillated between thinking that a "study in human nature" such as Varieties could contribute to a "Science of Religion" and the belief that religious experience involves an altogether supernatural domain, somehow inaccessible to science but accessible to the individual human subject.

James made some of his most important philosophical contributions in the last decade of his life. In a burst of writing in 1904-5 (collected in Essays in Radical Empiricism (1912)) he set out the metaphysical view most commonly known as "neutral monism," according to which there is one fundamental "stuff" that is neither material nor mental. In "A Pluralistic Universe" he defends the mystical and anti-pragmatic view that concepts distort rather than reveal reality, and in his influential Pragmatism (1907), he presents systematically a set of views about truth, knowledge,

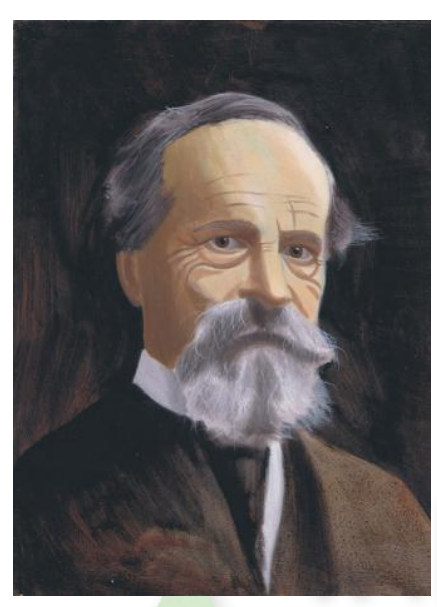
reality, religion, and philosophy that permeate his writings from the late 1870 s onwards.

[Portrait of William James (C) Darren McAndrew 2014]

William was precocious, highly intelligent, aware that he had no need to earn a living, yet very competitive with brother Henry and determined to seek distinction. Showing some skill in drawing, he first studied painting as a pupil of the well-known artist William Hunt, but soon abandoned hopes of an artistic career. However, it's clear that he had a well-developed artistic sensibility, and his later writings show an emotional sensitivity and a gift for metaphor and picturesque description. It was equally clear that he sought a greater distinction than he felt his artistic gifts could guarantee. In the end he chooses to study medicine, enrolling in 1861 in the Lawrence Scientific School at Harvard to study chemistry and comparative anatomy.

James then entered Harvard Medical School in 1864, but, under no pressure to qualify in order to practice, and still unsure of what he really wanted to become, he interrupted his medical studies twice. In 1865 he joined the famous Harvard biologist Louis Agassiz on an expedition to the Amazon to collect specimens for a new zoological museum. After resuming his studies he took another break, partly because of ill health and partly because he wanted to study in Europe. He finally completed his medical degree in 1869, but never practiced medicine, having neither need nor inclination to do so. Yet James was far from being a dilettante - rather, he was the opposite; a man diligently seeking his true vocation, and in the process becoming a polymath.

He began to see a way forward, and in 1873 chose to accept a position as an instructor in physiology and anatomy at Harvard. James had become deeply interested in what he called 'physiological psychology' - the issue of how creatures of flesh and blood could relate to the spiritual world of their experiences, beliefs and culture. From that point on his intellectual interests began to cohere, and his intellectual horizons continually expanded, resulting in the publication of his masterwork on psychology in 1890. His deep and abiding interest in people - 
what they did, what prompted their actions, how they reasoned, and how they related to one another - had two major consequences. It meant he shifted emphasis in the emerging discipline of psychology from the theoretical to the practical; and it meant he sought a new form of philosophy that was based on human beings rather than on depersonalized metaphysical abstractions.

\section{TIME LINE}

1. 1842. Born in New York City, first child of Henry James and Mary Walsh. James. Educated by tutors and at private schools in New York.

2. 1843. Brother Henry born.

3. 1848. Sister Alice born.

4. 1855-8. Family moves to Europe. William attends school in Geneva, Paris, and Boulogne-sur-Mer; develops interests in painting and science.

5. 1858. Family settles in Newport, Rhode Island, where James studies painting with William Hunt.

6. 1859-60. Family settles in Geneva, where William studies science at Geneva Academy; then returns to Newport when William decides he wishes to resume his study of painting.

7. 1861. William abandons painting and enters Lawrence Scientific School at Harvard.

8. 1864. Enters Harvard School of Medicine.

9. 1865. Joins Amazon expedition of his teacher Louis Agassiz, contracts a mild form of smallpox, recovers and travels up the Amazon, collecting specimens for Agassiz's zoological museum at Harvard.

10. 1866. Returns to medical school. Suffers eye strain, back problems, and suicidal depression in the fall.

11. 1867-8. Travels to Europe for health and education: Dresden, Bad Teplitz, Berlin, Geneva, Paris. Studies physiology at Berlin University, reads philosophy, psychology and physiology (Wundt, Kant, Lessing, Goethe, Schiller, Renan, Renouvier).

12. 1869. Receives M. D. degree, but never practices. Severe depression in the fall.

13. 1870-1. Depression and poor health continue.

14. 1872. Accepts offer from President Eliot of Harvard to teach undergraduate course in comparative physiology.

15. 1873. Accepts an appointment to teach full year of anatomy and physiology, but postpones teaching for a year to travel in Europe.

16. 1874-5. Begins teaching psychology; establishes first American psychology laboratory.

17. 1878. Marries Alice Howe Gibbens. Publishes "Remarks on Spencer's Definition of Mind as Correspondence" in Journal of Speculative Philosophy.

18. 1879. Publishes "The Sentiment of Rationality" in Mind.

19. 1880. Appointed Assistant Professor of Philosophy at Harvard. Continues to teach psychology.

20. 1882. Travels to Europe. Meets with Ewald Hering, Carl Stumpf, Ernst Mach, Wilhelm Wundt, Joseph Delboeuf, Jean Charcot, George Croom Robertson, Shadworth Hodgson, Leslie Stephen.

21. 1884. Lectures on "The Dilemma of Determinism" and publishes "On Some Omissions of Introspective Psychology" in Mind.

22. 1885-92. Teaches psychology and philosophy at Harvard: logic, ethics, English empirical philosophy, psychological research. 
23. 1890. Publishes The Principles of Psychology with Henry Holt of Boston, twelve years after agreeing to write it.

24. 1897. Publishes The Will to Believe and Other Essays in Popular Philosophy. Lectures on "Human Immortality" (published in 1898).

25. 1898. Identifies himself as a pragmatist in "Philosophical Conceptions and Practical Results," given at the University of California, Berkeley. Develops heart problems.

26. 1899. Publishes Talks to Teachers on Psychology: and to Students on Some of Life's Ideals (including "On a Certain Blindness in Human Beings" and "What Makes Life Worth Living?"). Becomes active member of the Anti-Imperialist League, opposing U. S. policy in Philippines.

27. 1901-2. Delivers Gifford lectures on "The Varieties of Religious Experience" in Edinburgh (published in 1902).

28. 1904-5 Publishes "Does 'Consciousness' Exist?," “A World of Pure Experience," "How Two Minds Can Know the Same Thing," "Is Radical Empiricism Solipsistic?" and "The Place of Affectional Facts in a World of Pure Experience" in Journal of Philosophy, Psychology and Scientific Methods. All were reprinted in Essays in Radical Empiricism (1912).

29. 1907. Resigns Harvard professorship. Publishes Pragmatism: A New Name for Some Old Ways of Thinking, based on lectures given in Boston and at Columbia.

30. 1909. Publishes A Pluralistic Universe, based on Hibbert Lectures delivered in England and at Harvard the previous year.

31. 1910. Publishes "A Pluralistic Mystic" in Hibbert Journal. Abandons attempt to complete a "system" of philosophy. (His partially completed manuscript published posthumously as Some Problems of Philosophy). Dies of heart failure at summer home in Chocorua, New Hampshire.

\section{REFERENCE}

1. "Philosophical Conceptions and Practical Results," 1898. Contained in Pragmatism, in The Works of William James, pp. 255-70.

2. "Remarks on Spencer's Definition of Mind as Correspondence," first published in The Journal of Speculative Philosophy, 1878. Contained in Essays in Philosophy, pp. 7-22.

3. A Pluralistic Universe. Cambridge, MA: Harvard University Press, 1977. Originally published in 1909 [PU].

4. Essays in Philosophy. Cambridge, MA and London: Harvard University Press, 1978 [E].

5. Myers, Gerald. (2001) William James: His Life and Thought. Yale University Press.

6. Pragmatism. Cambridge, MA: Harvard University Press, 1979. Originally published in 1907 [P].

7. Selected Letters of William and Henry James, Charlottesville and London, University Press of Virginia, 1997.

8. Simon, Linda (1999) Genuine Reality: A Life of William James. University Of Chicago Press.

9. Some Problems of Philosophy. Cambridge, MA and London: Harvard University Press, 1979. Originally published in 1911.

10. Talks to Teachers on Psychology and to Students on Some of Life's Ideals. New York: Henry Holt, 1899 [TT].

11. The Correspondence of William James, ed. Ignas K. Skrupskelis and Elizabeth M. Berkeley, 12 volumes. Charlottesville and London, University Press of Virginia, 1992-.

12. The Letters of William James, ed. Henry James, Boston: Little Brown, 1926.

13. The Meaning of Truth, Cambridge, MA and London: Harvard University Press, 1979 [MT]. Originally published in 1909.

14. The Principles of Psychology, Cambridge, MA: Harvard University Press, 1981. Originally published in 1890 [PP].

15. The Varieties of Religious Experience, New York: Longmans, Green, 1916. Originally published in 1902 [V].

16. The Will to Believe and Other Essays in Popular Philosophy, Cambridge, MA and London: Harvard University Press, 1979; first published in 1897 [WB].

17. The Works of William James, Cambridge, MA and London: Harvard University Press, 17 vol., 1975-.

18. William James: Writings 1878-1899. New York: Library of America, 1992. 